\title{
Deskripsi dan fenomena yang terjadi pada perkawinan alami sapi Peranakan Ongole (PO) dengan sapi Bali di Kandang Percobaan Loka Penelitian Sapi Potong
}

\author{
Jauhari Efendy, ${ }^{*}$, Frediansyah Firdaus \\ Loka Penelitian Sapi Potong Jln. Pahlawan No. 2 Grati Pasuruan Jawa Timur, 67184 \\ *Correspondence: jauhariefendy67@gmail.com
}

Received: May 28 ${ }^{\text {th }}, 2020$; Accepted: December 23 ${ }^{\text {th }}, 2020$; Published online: March $22^{\text {th }}, 2021$

\begin{abstract}
Abstrak
Tujuan: Untuk mengetahui pola tingkah laku perkawinan alam pejantan sapi POdengan sapi Bali pada sistem pembibitan menggunakan kandang kelompok "Model Litbangtan".

Metode: Materi yang digunakan 63 ekor; 3 ekor pejantan sapi PO dan 60 ekor betina sapi Bali. Penelitian didesain Rancangan Acak Kelompok (RAK) dengan tiga perlakuan berdasarkan status fisiologis sapi Bali; yaitu Perlakuan A: 20 ekor sapi dara, Perlakuan B: 10 ekor sapi dara dan 10 ekor sapi induk dan Perlakuan C: 20 ekor sapi induk. Parameter yang diamati pola perilaku estrus, lama waktu terjadinya estrus sampai kawin, fenomena yang terjadi selama kebuntingan dan proses kelahiran serta angka kebuntingan.

Hasil: Intensitas estrus kategori +++ lebih tinggi dibandingkan + maupun ++ pada semua perlakuan. Rataan terpendek jarak waktu terjadinya estrus sampai kawin terjadi pada Perlakuan A dengan capaian angka kebuntingan 83,33\%. Fenomena yang terjadi selama kebuntingan dan saat kelahiran adalah abortus, distokia dan kematian pedet saat lahir. Abortus terjadi pada umur kebuntingan 4-6 bulan didominasi sapi dara; kejadian distokia seluruhnya dialami sapi dara.

Kesimpulan: Sapi yang estrus sebanyak $86,67 \%$ dengan ekspresi beragam mulai silent heat $(+)$, sedang (++) maupun nampak (+++). Sapi Bali yang menunjukkan perilaku normal pada rangkaian aktivitas reproduksi (estrus dan kawin) sebanyak 42 ekor dengan jarak waktu terjadinya estrus sampai kawin antara 0,67-14,75 jam. Angka kebuntingan 83,33\%; fenomena yang terjadi selama kebuntingan dan proses kelahiran meliputi abortus, pedet mati saat lahir dan distokia.
\end{abstract}

Kata Kunci: Sapi Peranakan Ongole dan Bali; Kawin alam; Angka kebuntingan

Abstract

Objective: To determine the natural mating behavior pattern of PO bulls with Bali cows in the cattle breeding system using freestall housing of "Litbangtan Model".

Methods: The materials were 63 livestock; 3 PO bulls and 60 Bali cows. The study was designed with a randomized block design (RBD) with three treatments based on the physiological status of Bali cows; namely Treatment A: 20 heifers, Treatment B: 10 heifers and 10 cows, and Treatment C: 20 cows. The parameters observed were the pattern of estrous behavior, the length of time from estrus 
to mating, the phenomena that occurred during pregnancy and the birth process, and the pregnancy rate.

Results: The estrous intensity in the +++ category was higher than + or ++ in all treatments. The shortest average time interval between estrus and mating occurred in treatment A with a pregnancy rate of $83.33 \%$. The phenomena that occur during pregnancy and at birth are abortion, dystocia and calf death at birth. Abortion occurs at 4-6 months of gestation, dominated by heifers; the incidence of dystocia is entirely experienced by heifers.

Conclusion: Cows with estrus were $86.67 \%$ with various expressions starting from silent heat $(+)$, medium (++) and visible (+++). There are 42 Bali cows that show normal behavior in a series of reproductive activities (estrus and mating) with a time interval estrus and mating between 0.67-14.75 hours. Pregnancy rate $83.33 \%$; the phenomena that occur during pregnancy and childbirth include abortion, calf death at birth and dystocia.

Keywords: PO bulls and Bali cows; Natural mating; Pregnancy rate

\section{PENDAHULUAN}

Peningkatan populasi dan perbaikan mutu genetik sapi potong menjadi aspek yang sangat penting dalam memenuhi kebutuhan protein hewani masyarakat Indonesia. Adanya berbagai rumpun sapi potong baik lokal maupun silangan membuka peluang akan semakin tumbuh dan berkembangnya usahatani sapi potong karena peternak maupun pengusaha sapi potong memiliki banyak alternatif dalam memilih jenis sapi yang diusahakan sesuai potensi sumberdaya yang ada maupun prospek pasar. Hal ini karena usaha sapi potong merupakan bidang usaha yang sangat potensial untuk dikembangkan serta diproduksi dalam jumlah cukup untuk memenuhi kebutuhan masyarakat [1].

Kawin alam pada sapi potong saat ini masih banyak diterapkan peternak rakyat terutama pada budidaya semi intensif dan ekstensif maupun untuk wilayah yang masih belum tersentuh program inseminasi buatan (IB) atau bagi komunitas peternak sapi yang tidak tertarik dengan IB. Tingginya implementasi kawin alam pada ternak sapi disebabkan aplikasi IB di lapang masih mengalami kendala berupa jangkauan pelayanan IB yang masih terbatas akibat pola pemeliharaan sapi yang masih bersifat tradisional dan skala kepemilikan yang rendah [2].

Sistem persilangan pada sapi potong telah dipraktikkan oleh petani/peternak sejak lama. Pada sistem ini umumnya peternak penghasil sapi potong silangan mempertahankan rumpun murninya dan menjual anak hasil persilangan kepada peternak lain untuk persilangan selanjutnya atau dipotong. Fenomena ini apabila dibiarkan tanpa adanya program dan kebijakan yang tepat dalam bidang pemuliaan akan mengancam plasma nutfah sapi lokal Indonesia [3]. Depison [4] melaporkan bahwa persilangan antara pejantan sapi $\mathrm{PO}$ dengan induk sapi Bali pernah dilakukan di Kabupaten Batanghari Provinsi Jambi dengan hasil bahwa turunannya memiliki rataan bobot sapih sebesar 111,66 $\pm 7,83 \mathrm{~kg}$ lebih tinggi $(\mathrm{P}<0,05)$ dibandingkan bobot sapih pedet dari induk sapi Bali yang dikawinkan dengan pejantan sapi Bali yaitu sebesar 108,61 $\pm 20,60 \mathrm{~kg}$.

Penerapan kawin silang (crossbreeding) antara dua rumpun sapi potong lokal yang berbeda belum banyak dilakukan oleh peternak maupun praktisi peternakan sapi potong lainnya. Perkawinan antara pejantan sapi Peranakan Ongole (PO) dengan Bali telah dilakukan oleh Loka Penelitian Sapi Potong yang bertujuan menghasilkan kandidat rumpun baru sapi potong yang mengombinasikan sifat-sifat rumpun yang dikehendaki sekaligus mengurangi sifat-sifat yang tidak menguntungkan.

\section{MATERI DAN METODE}

\section{Tempat dan Waktu Penelitian}

Penelitian dilaksanakan di Kandang Percobaan Loka Penelitian Sapi Potong, berlokasi di Jalan Pahlawan No. 2 Kec. Grati Pasuruan Jawa Timur; selama 12 bulan. 


\section{Materi dan Bahan Penelitian}

Menggunakan 63 ekor sapi; dengan rincian 60 ekor sapi Bali sebagai indukan dan 3 ekor sapi PO sebagai pejantan. Perkawinan dilakukan secara alami (kawin alam) menggunakan Kandang Kelompok "Model Litbangtan" yaitu tipe kandang untuk perkawinan alam pada sapi potong yang didalamnya berisi 1 ekor pejantan bersama sejumlah ekor betina (induk/ dara) dengan cara sapi dilepas yang bertujuan meningkatkan efisiensi pengelolaan reproduksi dan tenaga kerja [5]. Penelitian menggunakan tiga unit kandang dengan tiga perlakuan berdasarkan status fisiologis sapi Bali; yaitu Perlakuan A = terdiri atas 20 ekor sapi dara; Perlakuan B = 10 ekor sapi dara dan 10 ekor sapi induk; dan Perlakuan $\mathrm{C}=20$ ekor sapi induk.

Masing-masing kandang berukuran $6 \mathrm{~m}$ x $12 \mathrm{~m}$ atau luas $72 \mathrm{~m}^{2}$ berisi 1 ekor pejantan dan 20 ekor betina atau dengan rasio 1 : 20 . Untuk mengetahui aktivitas perkawinan digunakan tenaga pengamat sebanyak tiga orang secara bergiliran setiap 8 (delapan) jam selama 24 jam dalam kurun waktu 3 (tiga) bulan.

\section{Rancangan Penelitian}

Penelitian ini didesain dengan Rancangan Acak Kelompok (RAK). Data profil sapi PO dan Bali, intensitas estrus, jarak waktu terjadinya estrus sampai kawin serta angka kebuntingan dianalisa menggunakan statistik deskriptif. Untuk melihat hubungan antara pengkategorian status fisiologis dengan kejadian distokia, abortus dan mati saat lahir (MSL) dianalisis menggunakan phi and cramer's $V$ dengan tingkat signifikansi (level of significant) 0,05 dan penafsiran kekuatan hubungan: 0,00 sampai 0,199; dimana 0,20 sampai 0,39 (rendah); 0,40 sampai 0,59 (sedang); 0,60 sampai 0,79 (kuat) dan 0,80 sampai 1,00 (sangat kuat) [6]; artinya jika P-Value $<0,05$ maka ada hubungan antara pengkategorian status fisiologis dengan fenomena yang terjadi selama masa kebuntingan dan proses kelahiran (distokia, abortus dan mati saat lahir).

\section{Parameter Penelitian}

Parameter yang diamati adalah (i) pola perilaku estrus; pengukurannya berdasarkan intensitas estrus menggunakan tiga simbol yaitu: + (birahi tenang), ++ (birahi sedang) dan +++ (birahi nampak/jelas) [Yusuf, 1990 dalam 7], (ii) lama waktu terjadinya estrus sampai kawin; penghitungannya mulai terlihat gejala estrus sampai ternak tersebut dikawini oleh pejantan menggunakan satuan menit, (iii) fenomena yang terjadi selama masa kebuntingan dan proses kelahiran; meliputi proses kelahiran, distokia, abortus dan mati saat lahir (MSL), dan (iv) angka kebuntingan, dihitung berdasarkan jumlah sapi yang bunting dibagi total jumlah sapi yang dikawinkan dikalikan seratus persen [8]; pemeriksaan kebuntingan (PKB) dilakukan tiga bulan setelah sapi dikumpulkan dalam kandang kelompok kawin menggunakan kandang jepit. Untuk lebih memastikan kondisi kebuntingannya, juga dilakukan analisa kandungan hormon progesteron menggunakan spesimen serum darah di Laboratorium Kebidanan Fakultas Kedokteran Hewan (FKH) Universitas Airlangga Surabaya.

\section{HASIL}

\section{Profil sapi PO dan Bali}

Pejantan sapi PO yang digunakan sebagai pemacek merupakan hasil perkembangbiakan dari kegiatan penelitian Pembentukan Pejantan Sapi PO kelahiran tahun 2009, 2010 dan 2011. Berdasarkan rekording, ketiga pejantan tersebut telah cukup lama digunakan sebagai pemacek untuk perbanyakan bibit sapi PO di Kandang Percobaan Loka Penelitian Sapi Potong dan memiliki performans reproduksi yang cukup baik. Performa pejantan sapi PO disajikan pada Tabel 1.

Sapi Bali yang digunakan berasal dari hasil penjaringan oleh Loka Penelitian Sapi Potong. Dari sejumlah 60 ekor sapi Bali yang digunakan sebagai materi penelitian, sebanyak 30 ekor berstatus fisiologis sebagai sapi induk sedangkan 30 ekor lainnya dara. 
Tabel 1. Bobot badan dan ukuran morfologi tubuh pejantan sapi PO

\begin{tabular}{ccccccc}
\hline $\begin{array}{c}\text { Lokasi } \\
\text { kandang }\end{array}$ & $\begin{array}{c}\text { No. ternak/ } \\
\text { ear tag }\end{array}$ & $\begin{array}{c}\text { Bobot Badan } \\
(\mathrm{kg})\end{array}$ & $\begin{array}{c}\text { Tinggi Badan Tinggi Kemudi Panjang Badan } \\
(\mathrm{cm})\end{array}$ & $\begin{array}{c}\text { Lingkar Dada } \\
(\mathrm{cm})\end{array}$ & $\begin{array}{c}\text { (cm) } \\
(\mathrm{cm})\end{array}$ \\
\hline A & $11 / 72$ & 417,00 & 138,50 & 146,50 & 129,00 & 173,00 \\
B & $09 / 67$ & 425,00 & 136,00 & 139,00 & 121,00 & 171,00 \\
C & $10 / 90$ & 485,00 & 141,00 & 144,00 & 125,00 & 186,00 \\
\hline
\end{tabular}

Tabel 2. Rataan bobot badan dan ukuran morfologi tubuh sapi Bali

\begin{tabular}{|c|c|c|c|c|c|c|c|c|c|c|}
\hline \multirow{3}{*}{ Perlakuan } & \multirow{2}{*}{\multicolumn{2}{|c|}{$\begin{array}{c}\text { Bobot badan } \\
(\mathrm{kg})\end{array}$}} & \multicolumn{8}{|c|}{ Rataan ukuran morfologi tubuh $(\mathrm{cm})$} \\
\hline & & & \multicolumn{2}{|c|}{ Tinggi badan } & \multicolumn{2}{|c|}{ Tinggi kemudi } & \multicolumn{2}{|c|}{ Panjang badan } & \multicolumn{2}{|c|}{ Lingkar dada } \\
\hline & Rataan & SD & Rataan & SD & Rataan & SD & Rataan & SD & Rataan & SD \\
\hline A & 183,25 & 28,46 & 111,56 & 4,79 & 113,00 & 5,29 & 108,94 & 6,31 & 140,61 & 8,05 \\
\hline B & 181,79 & 28,11 & 106,76 & 3,80 & 109,53 & 4,16 & 103,26 & 4,67 & 138,50 & 9,93 \\
\hline C & 186,34 & 30,74 & 105,56 & 4,53 & 108,19 & 3,99 & 104,34 & 4,78 & 142,75 & 10,19 \\
\hline
\end{tabular}

Keterangan : $\mathrm{SD}=$ standar deviasi

Tabel 3. Intensitas estrus sapi Bali

\begin{tabular}{cccccc}
\hline \multirow{2}{*}{ Perlakuan } & \multirow{2}{*}{$\mathrm{n}(\mathrm{ekor})$} & \multicolumn{3}{c}{ Intensitas estrus } & Jumlah sapi estrus \\
\cline { 3 - 5 } & & + & ++ & +++ & (ekor) \\
\hline A & 20 & $1(7,14 \%)$ & $6(42,86 \%)$ & $7(50,00 \%)$ & 14 \\
B & 20 & $5(25,00 \%)$ & $7(35,00 \%)$ & $8(40,00 \%)$ & 20 \\
C & 20 & $3(16,67 \%)$ & $7(46,67 \%)$ & $8(44,44 \%)$ & 18 \\
\hline Jumlah (ekor) & 60 & 9 & 20 & 23 & 52 \\
\hline
\end{tabular}

Keterangan : +: diam atau menaiki sapi lain; + +: keluar lendir dan/atau 3-A (vulva warna merah, bengkak, hangat); +++: keluar lendir, 3-A dan menaiki sapi-sapi lain

\section{Pola Perilaku Estrus}

Sapi Bali yang mengalami estrus sebanyak $86,67 \%$ dengan rentang waktu 2 sampai 26 hari setelah berada di dalam kandang; dengan kejadian estrus terbanyak pada interval waktu 4 sampai 16 hari yaitu sebanyak 32 ekor (61,54\%). Pola perilaku estrus menunjukkan ekspresi yang beragam mulai dari birahi tenang (silent heat), sedang atau kurang nampak sampai munculnya tanda-tanda yang mudah dideteksi (birahi nampak) seperti adanya gejala yang dikenal dengan istilah abang, abuh, anget (3A) yaitu vulva berwarna merah, bengkak dan hangat diiikuti keluarnya lendir, sapi gelisah dan nafsu makan turun, hingga menaiki dan diam dinaiki sesama sapi lainnya [7].

Pada seluruh perlakuan sapi Bali yang memiliki intensitas estrus ++ (dua plus) maupun +++ (tiga plus) lebih tinggi dibandingkan yang + (satu plus). Hal tersebut menunjukkan bahwa dari seluruh sapi yang estrus tersebut sebagian besar $(82,69 \%)$ memiliki pola perilaku estrus yang akurat serta kualitas estrus yang baik.

\section{Jarak Waktu Mulai Terjadinya Estrus Sampai Kawin}

Pada umumnya ketika proses perkawinan (kopulasi), sapi-sapi betina mengalami jatuh/roboh akibat tidak kuat menahan beban (bobot badan) sapi pejantan yang memiliki bobot badan lebih besar dibandingkan sapi Bali; walaupun demikian proses perkawinan bisa berlangsung dengan baik. Sapi Bali yang mengalami estrus dan dikawini pejantan pada masing-masing perlakuan disajikan pada Tabel 4 .

\section{Angka Kebuntingan serta Fenomena yang Terjadi Selama Kebuntingan dan Proses Kelahiran}

Hasil pemeriksaan kebuntingan secara palpasi rektal terdapat 35 ekor (58,33\%) sapi yang bunting, 11 ekor (18,33\%) dubius atau meragukan dan 14 ekor (23,34\%) negatif. Sementara itu, berdasarkan hasil analisa hormon progesteron, menunjukkan angka yang sangat berbeda yaitu terdapat 58 ekor $(96,67 \%)$ dinyatakan bunting yang ditunjukkan dengan konsentrasi kandungan 
Tabel 4. Jarak waktu terjadinya estrus sampai kawin pada sapi Bali

\begin{tabular}{cccccc}
\hline \multirow{2}{*}{ Perlakuan } & Jumlah induk yang estrus dan & \multicolumn{4}{c}{ Lama waktu estrus sampai kawin (menit) } \\
\cline { 3 - 6 } & dikawini pejantan (ekor) & Tercepat & Terlama & Rataan & SD \\
\hline A & 9 & 40 & 225 & 141,50 & 76,26 \\
B & 15 & 45 & 724 & 240,67 & 181,18 \\
C & 18 & 75 & 885 & 372,29 & 257,89 \\
\hline
\end{tabular}

Keterangan $: \mathrm{SD}=$ Standar deviasi

Tabel 5. Rekapitulasi hasil pemeriksaan kebuntingan pada sapi Bali

\begin{tabular}{ccccccc}
\hline \multirow{2}{*}{ Perlakuan } & \multicolumn{3}{c}{$\begin{array}{c}\text { PKB secara palpasi rektal } \\
\text { (ekor) }\end{array}$} & \multicolumn{3}{c}{ PKB berdasarkan kandungan hormon progesteron } \\
\cline { 2 - 7 } & Positif (+) & Negatif (-) & Dubius & Positif (+) & Negatif (-) $\begin{array}{c}\text { Rataan kandungan hormon } \\
\text { progesteron (ng/ml) }\end{array}$ \\
\hline A & 12 & 7 & 1 & 20 & 0 & $9,14 \pm 2,71$ \\
B & 11 & 3 & 6 & 19 & 1 & $7,28 \pm 2,12$ \\
C & 12 & 4 & 4 & 19 & 1 & $8,21 \pm 2,54$ \\
\hline Jumlah (ekor) & 35 & 14 & 11 & 58 & 2 & - \\
\hline
\end{tabular}

Keterangan: $\mathrm{PKB}=$ Pemeriksaan kebuntingan

Tabel 6. Fenomena selama masa kebuntingan dan kejadian kelahiran pada sapi Bali yang dikawinkan dengan sapi PO

\begin{tabular}{ccccc}
\hline \multirow{2}{*}{ Perlakuan } & \multicolumn{4}{c}{ Fenomena masa kebuntingan dan kelahiran } \\
\cline { 2 - 5 } & Normal (ekor) & Abortus (ekor) & Distokia (ekor) & Pedet MSL \\
\hline A & 7 & 4 & 2 & 3 \\
B & 15 & 1 & 2 & 1 \\
C & 13 & 1 & 0 & 1 \\
\hline Jumlah (ekor) & 35 & 6 & 4 & 5 \\
\hline
\end{tabular}

Keterangan : MSL = mati saat lahir

hormon progesteron melebihi $7 \mathrm{ng} / \mathrm{ml}$. Kadar hormon progesteron sapi bunting diatas 24 hari setelah kawin berkisar 7,39-20,78 $\mathrm{ng} / \mathrm{ml}[9]$.

Berdasarkan data Tabel 6, angka kebuntingan riil sapi Bali sebanyak 50 ekor. Dari jumlah tersebut sebanyak $70 \%$ berhasil melahirkan secara normal. Fenomena yang terjadi selama masa kebuntingan dan saat proses kelahiran adalah terjadinya abortus, distokia dan pedet mati saat lahir. Abortus terjadi pada umur kebuntingan yang bervariasi antara 4-6 bulan dan terbanyak berasal dari ternak dengan status fisiologis sapi dara yaitu sebanyak 4 (empat) ekor dan sisanya sapi induk. Kejadian distokia sebanyak $8 \%$ dari jumlah sapi bunting dan semuanya dialami sapi dara (Perlakuan A dan B). Jumlah pedet yang mati saat lahir (stillbirth) sebagian besar dialami sapi dara. Fenomena ini sejalan dengan pendapat Yulyanto et al. [10] bahwa kegagalan kelahiran lebih banyak dialami pada sapi-sapi dara dibandingkan induk.

Kejadian abortus dan mati saat lahir tidak berkorelasi terhadap status fisiologis ternak yang ditunjukkan dengan p-value yang lebih besar dari 0,05. Hasil p-value uji phi and cramer's $V$ pada kejadian distokia sapi Bali sebesar 0,038 lebih kecil dari level of significant $(0,05)$ (Tabel 7$)$; artinya ada hubungan antara status fisiologis dengan kejadian distokia namun dengan kekuatan hubungan relatif rendah yang ditunjukkan dengan nilai Phi-Cramer Coefficient sebesar 0,267 [6].

\section{PEMBAHASAN}

Rekording atau catatan produktivitas seekor pejantan yang digunakan sebagai pemacek menjadi penting karena dapat mengidentifikasi kemampuan dalam mengawini induk sapi dan menghasilkan kebuntingan; dengan kriteria yang digunakan antara lain: (i) warna bulu dominan putih 
Tabel 7. Tabulasi silang variabel status fisiologis dengan fenomena selama kebuntingan dan proses kelahiran

\begin{tabular}{|c|c|c|c|c|c|}
\hline \multirow{3}{*}{ Status Fisiologis } & \multicolumn{2}{|c|}{ Gangguan Reproduksi } & \multirow{3}{*}{ Total } & \multirow{3}{*}{ Phi-Cramer Coefficient } & \multirow{3}{*}{ P-Value } \\
\hline & Positif & Negatif & & & \\
\hline & \multicolumn{2}{|c|}{ Abortus } & & & \\
\hline Dara & 4 & 26 & 30 & & \\
\hline Induk & 2 & 28 & 30 & & \\
\hline \multirow[t]{2}{*}{ Total } & 6 & 54 & 60 & 0,111 & 0,389 \\
\hline & \multicolumn{3}{|c|}{ Pedet mati saat lahir } & & \\
\hline Dara & 4 & 26 & 30 & & \\
\hline Induk & 1 & 29 & 30 & & \\
\hline \multirow[t]{2}{*}{ Total } & 5 & 55 & 60 & 0,181 & 0,161 \\
\hline & \multicolumn{2}{|c|}{ Distokia } & & & \\
\hline Dara & 4 & 26 & 30 & & \\
\hline Induk & 0 & 30 & 30 & & \\
\hline Total & 4 & 56 & 60 & 0,267 & 0,038 \\
\hline
\end{tabular}

kecuali pada bagian kepala, leher dan lutut berwarna agak gelap, (ii) badan besar, gelambir longgar dan menggantung, serta (iii) warna pada bulu mata, moncong dan rambut ekor berwarna hitam [11].

Dalam kaitannya dengan fertilitas seekor pejantan, menurut penelitian yang dilakukan Luthfi et al. [12] bahwa kemampuan utama dari pejantan adalah memproduksi semen dalam menentukan kesuburan yang didukung dengan kondisi baik pada beberapa penilaian diantaranya volume, konsistensi, motilitas serta persentase viabilitas dan abnormalitas.

Berdasarkan penampilan eksterior sapi Bali yang digunakan sebagai materi penelitian memiliki karakteristik warna bulu merah bata, terdapat warna putih berbentuk oval pada bagian belakang pantat, serta bulu rambut pada ujung ekor dan garis belut pada bagian punggung berwarna hitam [13]. Kriteria di atas sesuai Keputusan Menteri Pertanian Nomor: 325/Kpts/OT.140/ 1/2010 tentang Penetapan Rumpun Sapi Bali [14].

Rataan bobot badan sapi Bali yang digunakan dalam penelitian ini pada semua perlakuan relatif lebih tinggi dibandingkan sapi Bali pada penelitian yang dilakukan Soekardono et al. [13] dengan mengambil sampel sapi Bali di wilayah Pulau Lombok dan Sumbawa yaitu masing-masing memiliki rataan bobot badan sebesar $157,00 \mathrm{~kg}$ dan $172,93 \mathrm{~kg}$. Demikian juga rataan tinggi gumba (TG), panjang badan (PB) dan lingkar dada
(LD) yang lebih tinggi pada umur yang relatif sama dibandingkan sapi Bali yang berada di wilayah Lombok masing-masing berukuran sebesar 105,27 cm; 106,73 cm dan $133,00 \mathrm{~cm}$.

Dibandingkan sapi yang memiliki intensitas estrus + dan ++; maka sapi dengan intensitas estrus +++ cenderung menunjukkan perilaku yang komplit dan mudah dikenali sebagai sapi yang sedang estrus. Beberapa perilaku yang ditimbulkan relatif seragam; diantaranya keluar lendir pada bagian vulva, adanya pembengkakan dan warna kemerahan pada bagian vulva serta sering menaiki sapisapi lain [15].

Menurut Kune dan Najamudin [16], adanya perbedaan intensitas estrus pada sapi tidak selalu disebabkan aspek genetik melainkan faktor-faktor lainnya seperti kondisi ternak, aktivitas kerja yang dilakukan serta interaksi ternak. Sementara itu, adanya warna kemerahan, pembengkakan serta kondisi hangat pada vulva disebabkan tingginya hormon estrogen yang selanjutnya memberi respon kepada adenohipofisa untuk memicu denyut jantung sehingga meningkatkan aliran darah melalui pembuluh darah menuju vulva [17].

Faktor penentu kebuntingan pada sapi potong adalah ketepatan waktu kawin dihitung berdasarkan awal terjadinya estrus. Pada kawin alam di kandang kelompok "Model Litbangtan" eksistensi pejantan unggul yang mampu mengawini sejumlah ekor induk dalam kurun waktu tertentu 
sangat dibutuhkan yang diekspresikan dengan libido tinggi dan kualitas sperma yang baik. Saili et al. [18] menyatakan banyak peternak sapi potong di Sulawesi Tenggara terkendala keberadaan pejantan baik secara kuantitas maupun kualitas; sehingga fenomena tersebut secara periodik menghambat peningkatan populasi di tingkat peternak rakyat terutama pada wilayah yang belum tersentuh oleh inseminasi buatan (IB).

Jumlah keseluruhan sapi Bali yang menunjukkan perilaku normal pada rangkaian aktivitas reproduksi atau yang mengalami estrus sekaligus dikawini pejantan pada seluruh perlakuan sebanyak 42 ekor (70\%). Jarak waktu tercepat saat awal terjadinya estrus sampai kawin bervariasi pada masing-masing perlakuan yaitu antara 0,67 hingga 1,25 jam; sedangkan terlama 3,75 hingga 14,75 jam.

Hafez [19] menyatakan bahwa secara umum ternak sapi memiliki lama estrus 18 hingga 19 jam dan ovulasi terjadi 10 hingga 11 jam setelah berakhirnya estrus. Dengan demikian, kurun waktu antara terjadinya estrus sampai kawin sebagaimana ditunjukkan pada Tabel 4 memungkinkan sapi-sapi Bali dalam penelitian ini berpeluang bunting.

Angka kebuntingan yang dicapai dalam penelitian ini berada dalam kategori tinggi yaitu $83,33 \%$. Puspitasari et al. [20] melaporkan bahwa sapi Rambon yang merupakan hasil persilangan antara induk sapi Bali dan pejantan sapi PO memiliki persentase kebuntingan $82,30 \%$. Menurut Hardjopranjoto [dalam 21], angka kebuntingan atau conception rate pada ternak sapi yang ideal sebesar $60-75 \%$.

Capaian angka kebuntingan sapi Bali dalam penelitian ini bahkan lebih tinggi dibandingkan sapi Aceh yang diinduksi dengan sinkronisasi estrus menggunakan metode ovsynch sebagaimana hasil penelitian yang dilakukan Efendi et al. [22] yaitu sebesar $80 \%$. Demikian juga terhadap kandungan hormon progesteron pada semua perlakuan memiliki angka yang lebih tinggi yaitu antara $7,28 \mathrm{ng} / \mathrm{ml}$ sampai 9,14 $\mathrm{ng} / \mathrm{ml}$ dibandingkan sapi Aceh yang hanya sebesar 1,54 ng/ml [Nurhafni, 2013 dalam 22].
Beberapa hasil penelitian menunjukkan bahwa abortus dialami oleh sapi pada umur kebuntingan diatas 5 (lima) bulan [23]. Penyebabnya bisa dari faktor non genetik seperti lingkungan, manajemen, ketidakstabilan hormon maupun ketidaksiapan uterus untuk bunting [24].

Febrianila et al. [25] mendefinisikan distokia adalah kesulitan induk dalam proses melahirkan yang diakibatkan faktor induk dan/atau fetus, sehingga untuk keberhasilan kelahiran diperlukan bantuan manusia. Berdasarkan bentuk kejadiannya, distokia yang dialami sapi Bali dalam penelitian ini berupa fetalis [26]; yaitu terjadinya abnormalitas ukuran pada fetus karena pejantan yang digunakan sapi PO. Distokia atau kesulitan melahirkan biasanya terjadi pada sapi dara yang baru pertama kali melahirkan [27]; disamping itu juga disebabkan ukuran, jenis kelamin, kondisi dan letak fetus [25].

Aprily et al. [28] menyatakan bahwa kejadian pedet mati saat lahir disebabkan banyak faktor diantaranya pedet mengalami abses di persendian, prematur dan gangguan syaraf. Kematian pedet fase perinatal yaitu saat lahir sampai 24 jam setelah lahir juga dapat disebabkan minimnya manajemen kelahiran oleh peternak seperti kurangnya pengamatan menjelang kelahiran dan jumlah ternak sapi dalam satu kelompok (herd size) [29]. Lebih lanjut Bleul [30] menyatakan bahwa kematian pedet fase perinatal juga disebabkan umur dari induk, lama waktu kebuntingan, jenis kelamin dan bobot badan pedet. Pada sapi perah abortus dan pedet mati saat lahir (stillbirth) menempati persentase paling besar penyebab kegagalan lahir dan kematian pedet pasca lahir yaitu masingmasing sebesar $41,07 \%$ dan $40,18 \%$ [28].

\section{KESIMPULAN}

Jumlah sapi Bali yang mengalami estrus sebanyak $86,67 \%$ dengan ekspresi beragam mulai silent heat $(+)$, sedang $(++)$ maupun nampak (+++). Sapi Bali yang menunjukkan perilaku normal pada rangkaian aktivitas reproduksi (estrus dan kawin) sebanyak 42 ekor dengan jarak waktu terjadinya estrus sampai kawin antara 0,67-14,75 jam. 
Angka kebuntingan sapi Bali sebesar 83,33\%; namun demikian fenomena yang terjadi selama masa kebuntingan dan proses kelahiran meliputi abortus, pedet mati saat lahir dan distokia.

\section{KONFLIK KEPENTINGAN}

Tidak ada konflik kepentingan berkaitan dengan anggaran atau dana maupun penggunaan materi penelitian (ternak sapi, kandang, dan lain-lain) dalam penulisan naskah atau makalah ini.

\section{REFERENSI}

1. Sudirman. 2016. Pengaruh metode perkawinan terhadap keberhasilan kebuntingan sapi Donggala di Kabupaten Sigi. Jurnal Mitra Sains. 4(3): 22-27.

2. Iswoyo and P. Widiyaningrum. 2008. Performans reproduksi sapi Peranakan Simmental (Psm) hasil inseminasi buatan di Kabupaten Sukoharjo Jawa Tengah. J. Ilmu-Ilmu Peternakan. 11(3): 125-133. Doi: 10.22437/jiip.v.11i3.744.

3. Matondang, R. H., and S. Rusdiana. 2013. Langkah-langkah strategis dalam mencapai swasembada daging sapi/kerbau 2014. J. Litbang Pert. 32(3): 131-139. Doi: 10.21082/jp3.v32n3.2013.

4. Depison. 2010. Performans anak hasil persilangan induk sapi Bali dengan beberapa bangsa pejantan di Kabupaten Batanghari Provinsi Jambi. Jurnal Agripet. 10(1): 37-41. Doi: 10.17969/agripet.v10i1. 636.

5. Rasyid, A., J. Efendy and Mariyono. 2012. Sistem Pembibitan Sapi Potong Dengan Kandang Kelompok Model Litbangtan. Penerbit IAARD Press. Badan Litbang Pertanian. Kementerian Pertanian. Jakarta.

6. Sugiyono and A. Susanto. 2015. Teori dan Aplikasi untuk Analisis Data Penelitian. Penerbit Alfabeta. Bandung.

7. Kune, P. and N. Solihati. 2007. Tampilan birahi dan tingkat kesuburan sapi Bali Timor yang diinseminasi. Jurnal Ilmu Ternak. 7(1): 1-5. Doi: 10.24198/jit.v7i1. 2223.

8. Nabenishi, H., H. Ohta, T. Nishimoto, T. Morita, K. Ashizawa, and Y. Tsuzuki. 2011.
Effect of the temperature-humidity index on body temperature and conception rate of lactating dairy cows in Southwestern Japan. J. Reprod. Dev. 57(4): 450-456. Doi: 10.1262/jrd.10-135T.

9. Pemayun, T. G. O., I. G. N. B. Trilaksana, and M. K. Budiasa. 2014. Waktu inseminasi buatan yang tepat pada sapi Bali dan kadar progesterone pada sapi bunting. Jurnal Veteriner. 15(3): 425-430.

10. Yulyanto, C. A., T. Susilawati, and M. N. Ihsan. 2014. Penampilan reproduksi sapi Peranakan Ongole (PO) dan sapi Peranakan Limousine di Kecamatan Sawoo Kabupaten Ponorogo dan Kecamatan Tugu Kabupaten Trenggalek. J. Ilmu-Ilmu Peternakan. 24(2): 49-57.

11. Direktorat Jenderal Peternakan dan Kesehatan Hewan. 2011. Pedoman Intensifikasi Kawin Alam. Direktorat Jenderal Peternakan dan Kesehatan Hewan. Kementerian Pertanian. Jakarta.

12. Luthfi, M., T. Susilawati and N. Isnaini. 2015. Perbedaan kecepatan pubertas calon pejantan sapi PO yang dipelihara pada kelompok sex yang berbeda. J. Ternak Tropika. 16(2): 07-15. Doi: 10.21776/ub.jtapro.2015.016.02.2.

13. Soekardono, C. Arman, and L. M. Kasip. 2009. Identifikasi grade sapi Bali betina bibit dan koefisien reproduksi sapi betina di Propinsi Nusa Tenggara Barat. Buletin Peternakan. 33(2): 74-80. Doi: 10.21059/buletinpeternak.v33i2.119.

14. Kementerian Pertanian. 2010. Keputusan Menteri Pertanian No. 325/Kpts/OT.140/1/ 2010 tentang Penetapan Rumpun Sapi Bali. Direktur Perbibitan dan Produksi Ternak - Ditjen Peternakan dan Keswan. Kementerian Pertanian. Jakarta.

15. Hafizuddin, T. N. Siregar, M. Akmal, J. Melia, Husnurrizal, and T. Armansyah. 2012. Perbandingan intensitas berahi sapi Aceh yang disinkronisasi dengan prostaglandin $\mathrm{F}_{2}$ alfa dan birahi alami. Jurnal Kedokteran Hewan. 6(2): 81-83. Doi: 10.21157/j.ked.hewan.v6i2.296.

16. Kune, P. and Najamudin. 2002. Respon estrus sapi potong akibat pemberian progesteron, prostaglandin $\mathrm{F} 2 \alpha$ dan estradiol benzoat dalam kegiatan sinkronisasi estrus. Jurnal Agroland. 9(4): 
380-384.

17. Anisa, E., Y. S. Ondho and D. Samsudewa. 2017. Pengaruh body condition score (BCS) berbeda terhadap intensitas birahi sapi induk Simmental Peranakan Ongole (SIMPO). Jurnal Sain Peternakan Indonesia. 12(2); 133-141. Doi: 10.31186/ jspi.id.12.2.

18. Saili, T., L. O. Nafiu, L. O. Baa, S. Rahadi, A. Napirah, Syamsuddin, I. W. Sura and F. Lopulalan. 2017. Efektivitas sinkronisasi estrus dan fertilitas spermatozoa hasil sexing pada sapi Bali di Sulawesi Tenggara. Jurnal Veteriner. 18(3): 353-359. Doi: 10.19087/jveteriner.2017.18.3.353.

19. Hafez, E. S. E. 2000. Reproduction In Farm Animals. $7^{\text {th }}$ Ed. Reproductive Health Centre, Kiawah Island, South Carolina, USA.

20. Puspitasari, I. K., N. Isnaini, A. P. A. Yekti, T. Susilawati. 2018. Tampilan reproduksi sapi Rambon betina pada paritas yang berbeda. Ternak Tropika. 19(2): 80-86. Doi: 10.21776/ub.jtapro.2018.019.02.2.

21. Febrianthoro, F., M. Hartono, and S. Suharyati. 2015. Faktor-faktor yang mempengaruhi conception rate pada sapi Bali di Kabupaten Pringsewu. Jurnal Ilmiah Peternakan Terpadu. 3(4): 239-244. Doi: 10.23960/jipt.v3i4.p\%25p.

22. Efendi, M., T. N. Siregar, Hamdan, Dasrul, C. N. Thazmi, Razali, A. Sayuti and B. Panjaitan. 2015. Angka kebuntingan sapi lokal setelah diinduksi dengan protokol ovsynch. J. Med. Vet. 9(2): 159-162. Doi: 10.21157/j.med.vet.v9i2.3804.

23. Adjid, A. 2004. Strategi alternatif pengendalian penyakit reproduksi menular untuk meningkatkan efisiensi reproduksi sapi potong. Wartazoa. 14(3): 125-132.

24. Tulu, D., B. Deresa, F. Begna, and A. Gojam. 2018. Review of common causes of abortion in dairy cattle in Ethiopia. J. Vet. Med. Anim. Health. 10(1): 1-13. Doi: 10.5897/JVMAH2017.0639.

25. Febrianila, R., W. Paramita, T. Imam, I. Mustofa, E. Safitri, and H. A. Hermadi. 2018. Kasus distokia pada sapi potong di Kecamatan Kunir Kabupaten Lumajang Tahun 2015 dan 2016. Ovozoa. 7(2): 148-151. Doi: 10.20473/ovz.v7i2.2018.148151.

26. Toelihere, M. R. 2006. Ilmu Kebidanan pada Ternak Sapi dan Kerbau. Penerbit UI Pres. Jakarta.

27.Schuenemann, G. M. 2012. Calving Manajement in Dairy Herds: Timing of Intervention and Stillbirth. Ohio (USA): The Ohio State University.

28. Aprily, N. U., P. Sambodho and D. W. Harjanti. 2016. Evaluasi kelahiran pedet sapi perah di Balai Besar Pembibitan Ternak Unggul dan Hijauan Pakan Ternak Baturraden. Jurnal Peternakan Indonesia. 18(1): 36-43. Doi: 10.25077/jpi.18.1.3643.2016.

29. Cuttance E. L., W. A. Mason, J. McDermott, R. A. Laven, S. McDougall, and C. V. C. Phyn. 2017. Calf and replacement heifer mortality from birth until weaning in pasture-based dairy herds in New Zealand. J. Dairy Sci. 100(10): 8347-8357. Doi: 10.3168/jds.2017-12793.

30. Bleul, U. 2011. Risk factors and rates of perinatal and postnatal mortality in cattle in Switzerland. Livestock Science. 135(2-3): 257-264. Doi: 10.1016/j.livsci.2010.07.022. 